\title{
Integrated Disease Management on Grapes-A Pioneer of a Reformed Movement towards Sustainability
}

\author{
Siddhartha Das* and Sudeepta Pattanayak
}

Department of Plant Pathology, MS Swaminathan School of Agriculture, Centurion

University of Technology and Management, Paralakhemundi, Odisha, India

*Corresponding author

\begin{abstract}
A B S T R A C T
Sustainable agricultural intensification through integrated disease management (IDM) approaches is considered to be the most powerful tool for any developing country. The principles and components of integrated disease management approaches are crudely followed sustainable agriculture for our future generation and better soil health. These approaches must be incorporate into our farming system for better food security, armouring biodiversity and improving climate resilience. Grapes are the major tropical fruit crop in India and by huge production it generates substantial revenue in Indian agro-economic context. Every year each socio economic classes of farmers starting from small to marginal to big has facing some difficulties on gape production, diverse diseases attack, post-harvest management and marketing strategies and policies. Application of IDM skills in grape production is not only a challenging task but also wide adoptability of the same in farmer's level facing diverse barriers in global scenario. The fact revealed that inadequate and inappropriate knowledge and skills of IDM strategies are the major core component of this problem. IDM is found to be the most effective management strategy as because it's includes all the possible suggestive measure of disease management with an eco-friendly approach. For the successful implementation of IDM framework into our farming system Government activity and newly developed policies play an important role in all over the time. The present investigation is a review of studies and analysis of IDM centric barrier of grape production, forecasting and challenges.
\end{abstract}

\section{Ke y w o r d s}

IDM, grape, sustainable, ecofriendly.

\section{Article Info}

Accepted:

05 April 2020

Available Online:

10 May 2020

\section{Introduction}

Grapes (Vitis vinifera) are considered to be one of the major important tropical fruit crops in India belonging from the family Vitaceae and classified under berry fruit type. Review of literature revealed that this non-climactric fruit was originated from Western Asia and some parts of European continents. India holds second ranking in global fruit production. As per the latest statistics the area/production rate of grape production in 2018-19 is $137 \mathrm{Ha} / 2951 \mathrm{MT}$ which is comparatively higher than the last two years production rate $137 \mathrm{Ha} / 2922 \mathrm{MT}$ (2016-17) and $139 \mathrm{Ha} / 2920 \mathrm{MT}$ (2017-18) (NHB estimate, 2018-19 report). The active grapes production states are Maharasthra, Karnataka, Tamil Nadu, West Bengal. Tough grapes production takes an important role in Indian 
agro-economical context but every year farmers suffered with huge amounts of yield loss due to various biotic and abiotic stresses. Additionally post-harvest management, marketing, cost maintenance of agro investment including agro-chemical wages are makes the situation more severe. It's also found that irrelevant and excessive use of agro chemicals increase the increase phytotoxicity level and decrease soil health which is very much alarming and threatening for our future generation.

To combat with this situation we need an alternative approach of eco-friendly, nonhazardous, non-toxic tool as a pioneer reformer of sustainable agriculture. Integrated disease management (IDM) is the powerful arsenal which fulfills such needs.

Every year a large numbers of phytopathogen diversified as fungus, bacteria, viruses, attacks grape plant at different crop growth stages and resulting huge yield loss. The infection probability not only restrict at mature stage but also spreading through, seedling stage, pre-flowering, flowering and fruiting stage.

Farmers are also suffered several other problems like low investment capacity, increased labor charge and agrochemicals, non-availability of skilled labors, inadequate knowledge of disease management, postharvest management, improper and unscientific storage of harvested crops, communication gap in marketing strategy like import-export of harvested fruits on urgent basis through nationalized and international market etc.

Different kinds of manmade activities like changing in cropping pattern, crop introduction and intensification in one side control pathogenic population in some extent, in another side altering pathogenic adoptability with consecutive time with more virulency and breaks ecological balance (Buddenhagen, 1977). Rapidly growing agrochemical industry and various products destroyed agro-ecological balance for the present and future time.

It was observed that many factors are directly or indirectly associated with pathogenic emergence and resistance. Application of six core principles of IDM i.e. avoidance of the pathogen, exclusion of the pathogen, eradication of the pathogen, protection of the host, disease resistance and therapy are found to be effective in case of every diseases.

Epidemiological forecasting of diseases will possible by correlating environmental factors and consecutive pathogenic growth through regular based monitoring additionally which helps in disease prediction of agro-economic threshold level and modeling for a certain crop and selective pathogen (Khoury and Makkouk, 2010). Detail description of major grapes diseases and their management strategies are considered for this review along with glimpses of IDM practices based on farmer's centric problem prioritization discussed briefly.

\section{Emerging approaches of integrated disease management}

IDM is currently defined as "a sustainable potential tool kit of all combining disease management components i.e. biological, cultural, physical and chemical practices with an eco-friendly, non-hazardous, nontoxic approaches." This concept evolved from the original IPM definition after responding to today's call for ecologically based pest management. (Overton,1996). Farmer's centric problem prioritization, their concentric solution (Core A component) and peripheral environmental impact represented through Figure 1 and Figure 2. 


\section{Regular based monitoring}

Regular based crop monitoring, data checking and data validation with healthy previous year's crop situation at correlate to understand greater IDM sills in case of fruit cultivation. Its can generate the basic concept of disease development, disease progress and disease forecasting, additionally gain knowledge of particular pathogen and its behaviouristic study.

\section{Host-plant resistance}

Host plant resistance is the most effective IDM component to protect the crop from any kind of disease. It's also cost effective for poor farmers which relieved from excessive use of agro chemicals. Based on geographical position and every year disease severity track record, selection of resistant variety should be done accurately.

\section{Traditional or cultural practices}

Traditional or cultural practices are the alternative approach and effective to protect the crops against many diseases. It is found under several instances that such types of practices can reduce inoculums potentiality by decreasing the population and increasing nonnutritious food the pathogen. Crop rotation, ploughing, pruning are considered to be good cultural practices, additionally mulching, solarization and crop rotation can boost biocontrol potential of antagonists.

\section{Chemical control}

For long decades fungicides takes an important role in disease management. In the year of 1960, systemic fungicides started its journey and turned to be highly demanded for its greater effectivity and specificity. Triazole found to be most effective and covered almost $25 \%$ of the marketed demand (Hewitt, 1998).
Phenoxyquinolines, oxazolidinediones,

strobilurins, phenylpyrroles, anilinopyrimidines were newly developed fungicides with greater effectivity. Although gradual adoptability and fungicidal resistance makes the situation more challenging for every new products.

Newly developed products with their wide or narrower specificity may or may not be effective depends on modifying complex adoptability and fungicidal resistance of a particular pathogen (Gullino et al., 2000). Past experiences clearly indicating application of fungicidal level will be more effective under the umbrella of IDM (De warrd et al., 1993). Fungicidal industry should more responsible for the production of effective fungicide under the compatibility level of IDM and IPM, for better public health concern and environmental balance (Knight $e t$ al., 1997).

\section{Biological control}

The most promising non-hazardous, non-toxic eco-friendly strategy to control plant diseases are the application of biocontrol agents. The journey of diverse biocontrol agents started at long past by showing potential biocontrol property such as application of Trichoderma harzianum (Harman and Bjorkman, 1998) against Rhizoctonia, crown gall disease pathogen Agrobacterium radiobacter K84 (Kerr,1980) applied against seedling blight pathogen Pythium and several more like Streptomyces griseus (Cook et al., 1996) and Gliocaladium virens (Lumsden and walter, 1995) etc.

Searching of potential biocontrol antagonist was coming through long traditional way in terms of crop rotation and avoidance which remarkably decreases pathogen population and disease severity. Next route map coming with addition of manures and compost on the 
cultivated land for soil enrichment which unknowingly increases antagonistic microflora (Baker and Cook, 1974) resulted better yield with disease protection.

\section{Support system for the successful implementation of IDM framework}

For the proper implementation of IDM strategies and its core principles, following support system will needed -

\section{Construction of plant protection policy}

Construction of plant protection policy is based on the following strategies.

\section{Proper implementation of pest or disease management policy}

Pest and disease management act and policies established and implemented by Ministry of Agriculture to make a barrier against qualitative and quantitative yield loss. IDM promoting policies and activities are of different kinds like - establishment of regional and nationalized early warning and forecasting centers and digitalized tools, disease surveillance project and policies, plant disease clinic and information system which can reach all agro-economic classes of farmers very easily. In India different organizations like IIVR, NIPHM, IIHR played an important role in disease forecasting and management in case of fruits and vegetable diseases, additionally state and central agricultural Universities, KVK and several more organization promoting IDM and IPM from their end.

\section{Construction of eco-balance pesticide management policy}

Following of IDM or IPM principles will possible only by maintaining exact doses into agricultural sector. Fungicide and pesticide registration, toxicity index and labeling is very much important for initializing IDM and IPM and consciousness among general farmers. In addition regulations and guidelines of application methods, authorize personal of distribution and selling, proper biosafety measure, scientific equipment, clothing and proper disposal of agri-waste should maintain properly. Banning and taxing of hazardous, toxic agro-chemicals should strictly maintain in case of agrochemical trading. Alternative approach of those toxic agro-chemicals must be available in the market by which farmers can't be cheated and exact license holder persons should sell and transferred that knowledge (Shcillhorn van veen , 1999). Government of developing countries takes various initiation like pesticide elimination and tax relaxation policy (SPIPM, 2008), organic farming certification and promoting policies etc which can motivate farmers in organic farming.

\section{Establishment of plant quarantine}

Quarantine is one of the legislative measure by which pathogen can stopped before introduced in a particular region. Pest and disease risk analysis, surveillance and regular based monitoring can helps to identify destructive pathogen-pest in a particular region, their emerging probability and their nature of severity, which can easily forecast about the requirement of quarantine. Disease risk analysis, forecasting and modeling can predict any pathogenic emergence in a particular region with potential dimensions of quarantine under the umbrella of IDM.

\section{Seed certification including vegetative propagation material}

Most of the plant diseases and pests are seed borne and seed transmitted therefore it is needed seed treatment or cleaning of the planting material. This types of strategy is 
under IDM programme. Quality control, cost effectivity of those materials should easily available to the farmers, by which they can easily adopt the IDM. Implementation of those national policies in terms of seed certification, vegetative propagule certification should be done properly. Time to time revision of those policies highly needed. If those policies are not properly constructed and revised then accessibility, economic feasibility and practicality of IDM policies to needful farmers became blocked.

\section{To construct private sector investment policy}

Private sector investment policies sometimes found to be effective in case of IDM adoption. But it may have some positive or negative impact. This type of policies clearly indicates involvement of private industries and their restriction of product development under IDM and IPM umbrella. This may be in terms of bio-pesticides production, pheromones, different agro-chemicals, disease free seeds and propagules, resistant variety development, PGPR and biocontrol agents development. Government support in terms of small to large scale loan sanction for industry establishment under IDM promotion could be effective and encouraging for all kinds of investor and investment policies.

\section{To construct trade and export policy}

Disease and pest management through international trade regulation, intellectual property rights and food safety found to be the very much effective to establish IDM and IPM (Sorby et al., 2003). Management of trans-boundary diseases i.e. transferred through any biological or mechanical means from one country to another or through travelers (like wheat rust and soyabean) should be a global concern and international cooperation needed in this matter to control emergence of any virulent pathogen in a noninfected area or country.

Idealistic implementation of laws regarding food safety, public health, and environment

Food safety regulations or pesticide or food adulterants are the matter of global concern. Diverse mycotoxins are also considered as food contaminants, which through direct or indirect consumption may arise severe health diseases. Public health and environmental safety issues like water, soil, air contamination through pesticide or hazardous agro chemicals may destroy ecological balance and alarming for sustainable agriculture and sustainable biosphere. Although regulatory systems for the use of pesticides or GMOs governments minimize environmental and public health hazards by maintain a proper balance between the costs and benefits of these technologies (Schillhorn van Veen, 1999). These type of regulatory systems every time facing new problems and challenges.

\section{Making of land use policy}

In case of all developing countries land use policy is one most important policy to maintain IDM properly. Land tenure arrangements are considered as limiting factor for the successful adoption of sustainable crop production activities and IDM strategies by farmers. Land size and land ownership ate the two important factors under the land use policy. These factors are consider to be the point of motivation for the farmers to adopt new technologies and IDM skills for long term basis. It is also found crop and genetic diversity in a larger landscape, including gene deployment strategies, monoculture in time and space, cultivated varietal reduction, management of field hedges harbouring natural enemies or planting of secondary hosts to the pathogens are all factors that 
would directly affect for the reduction of pathogen population and promoting IDM strategies and their scaling up at a regional or national level.

\section{Establishment of education and awareness policy}

Farmers education and awareness policies are the utmost important of all the policies. Knowledge and skill transfer of IDM and wide adoptability of the same is only possible through Government sponsored farmers awareness policy. Food safety and environmental risk can be significantly control if we raising the fact as a major problem in front of farmers. Excessive use of agrochemicals should be checked and recommended under proper guideline. Food safety related policies are of different types like controlling of mycotoxins and excessive use of pesticides etc. Farming systemic chains like policy makers, farmers and consumers are need to check the impact and significance of the IDM or IPM in practical way and has proven to be good strategy to get the national support to IPM and IDM programmes through policies, regulations, and funding (van de Fliert et al., 2000). In India different agricultural universities, institutes, KVK, and some other government or nongovernment agencies takes an important role and organize different training programmes round the year. Government of India gives the facility to the farmers for toll free telephonic agri care service with their concurrent problems.

\section{Construction of agricultural extension policy}

Ministry of Agriculture, Government of India, promoting IDM/IPM policies through Agricultural extension policy for the long time. In 2002, Sulaiman and Hall explained that technology and knowledge are the bidirectional way of the same route and skills will transferred to the farmers through extension specialist. Farmers centric problem solving and management capacity can only improved through practical field based joint learning programme (Hagmann etal., 1999; Roling and Pretty, 1997). Both state and central government equally participates agricultural extension policy and its development. Each year farmers centric budget amendment will proposed and allotted to poor needy farmers in terms of financial loans, lands, free seeds and agrochemicals etc for the improvement of farming policy which directly or indirectly promotes and boost IDM strategies.

\section{Diseases of Grapes (Vitis vinifera L.) and their Management}

Grape (Vitis vinifera L.) is one of the major fruits known to mankind from long past. It is well known for its delicacy and its role in wine production. The world-wide area under this crop is approximately 7.33 million hectares while the average productivity of 7.83 ton/ha (FAO, 2000).Developing a disease management program is a unique challenge to control all the diseases of grapes at a time. For a successful IDM, all the control measures must be integrated. Different diseases which act as a severe biotic stresses on Indian grapes production and priority based concentric IDM components is represented through Figure 3.

\section{Black rot}

The fungus Guignardia bidwellii is responsible for this disease development. The pathogen overwinters in mummified fruit or on the ground. Airborne ascospores and conidia from the mummified fruits releases after the spring rain. Primary infections develop on leaf if all environmental factors are conducive. Previous studies have stated that the ascospores from mummies on the 
ground are discharged from one-inch shoot growth to 2 to 3 weeks after bloom. The hanged mummified fruits are known to infect the plant throughout the season.

\section{Symptoms}

On the dorsal side of the leaf, Brown colored round and scattered lesions are observed. Fungal fruit bodies (pycnidia) are observed on the lesions.

\section{Management}

\section{Cultural}

As mummified fruits play an important role in disease spreading, Sanitation is highly needed. All hanged mummies should be removed from the vineyard.

\section{Chemical}

Mancozeb, Ziram are highly effective against this disease. The fungicides should be sprayed before the entry of pathogen to protect the plants.

\section{Powdery mildew}

Powdery mildew is a major disease of grapes as it is responsible to reduce vine growth, quality of fruit, its yield etc. It is caused by a fungus Erysiphe necator.

\section{Symptoms}

The pathogen attacks the green parts of vine, leaves, inflorescence and berries. White patches of powder, consisting conidia and conidiophore can be observed on both side of the leaf. Later on, the patches enlarge and coalesce, covering the whole surface of the leaf. In severe case, the leaves curl, fall off and spread to canes, tendrils, panicles and berries. Under the powdery growth, black discolored patches can be seen. Infection on inflorescence lead to poor fruit set or premature fruit drop and sometimes berry becomes dark in colour, crack and finally rot.

\section{Management}

\section{Cultural}

Proper plant population should be maintained for sunlight penetration and good air circulation. Application of excess fertilizer should be avoided. Long duration overhead sprinklers are advisable. The infected parts should be pruned and destroyed.

\section{Chemical}

Any type of Sulphur spray is effective against this pathogen. The best sulphur products to use for powdery mildew control are wettable sulphurs. Sulphur products have been used to manage powdery mildew for centuries but are only effective when applied before disease symptoms appear. Difenoconazole (Inspire) or Tebuconazole (Mettle) is effective against this disease.

\section{Biological}

The active bacterium, Bacillus subtilis helps to prevent the powdery mildew from infecting the plant. To eradicate powdery mildew infections, plant-based oils such as neem oil or jojoba oil can also be used. The spray application off plant oils should be avoided till 2 weeks of Sulphur spray.

\section{Phomopsis cane and leaf spot}

The fungus Phomopsis viticola is responsible for this disease.

\section{Symptoms}

When the Berry reach the harvesting stage, infections first appear as a light-brown colour with prominent Black spore (pycnidia). In 
severe case, the spores enter to the berry and the berry shrivels. The fungus remains in "Latent" stage in green fruits. In ripening stage, the fungus causes the fruit to rot.

\section{Management}

\section{Cultural}

Vineyard sanitation is utmost important. Proper air circulation should be maintained to reduce the humidity.

\section{Chemical}

Contact fungicides like mancozeb or ziram should be applied after each rainfall. A dormant application of liquid lime sulfur may be beneficial incontrol.

\section{Eutypa dieback}

This disease is caused by the fungus Eutypa lata.

\section{Symptoms}

The symptoms are mainly observed in spring season and 2 to 4 years of first infection. Shoot growth is weak and stunted in diseased plants. Later on, Leaves become small, cupped, distorted, and yellow. In severe case, the total vine dies. The earliest symptom to develop is a canker in older wood of the main trunk which normally starts after pruning. As it is covered with bark, it is very difficult to observe. Removal of bark over the canker reveals a darkened or discolored wood with white, healthy wood near the surrounding area.

\section{Management}

\section{Cultural}

The infected plants should be removed and destroyed. The best time to identify and remove infected vines is in early spring. Proper field Sanitation is advisable. The double trunk system should be followed for pruning of vines.

\section{Chemical}

Fungicide recommendations currently are not available for control of this disease.

\section{Downy mildew}

Downy mildew is a critical disease of grapes in India. The fungus (Plasmopara viticola) causes this loss by infecting inflorescences, clusters and shoots.

\section{Symptoms}

Initially, circular yellow oils spots can be seen on leaves and white to black patches can be seen underside of these spots. In resistant plants, small, angular, inter venial patches of diseased cells is observed in older leaves. In severe case, susceptible young bunches turn brown and die quickly. Later, 3-4 weeks after fruit set, berries gain resistance to infection.

\section{Management}

\section{Pre-infection fungicides (protectants)}

It mainly includes contact fungicides and protect the foliage and vines by stopping the spores germinating. The pre-infection fungicides include: dithiocarbamates (eg mancozeb, thiram, ziram) or captan or quinone etc.

\section{Post-infection fungicides (eradicants)}

These are systemic fungicides. These fungicides kill the pathogen inside infected tissue. Mixture of Mancozeb and Ridomil is usually provides a protective defense against new infection. The post-infection fungicides include Ridomil Gold, Mancozeb etc. 


\section{Botrytis bunch rot}

Botrytis bunch rot (gray mold) is caused by Botrytis cinerea. The fungus grows and multiplies on dead plant tissue. Botrytis bunch rot is mainly severe in tight, closely packed clusters of fruit cultivars.

\section{Symptoms}

Dull green spots limited with the veins are observed on leaves and fruits. This spot rapidly turns to a brown necrotic lesion. The fungus is also responsible for blossom blight, stem blight and etc. In severe conditions, the ripening berries rot and infection spread to other branches. White berries turned to brown and shriveled while purple variety become reddish colour. In suitable environmental condition, fluffy growth and grayish brown mature spores can be seen.

\section{Management}

\section{Cultural}

Proper plant population should be maintained for air circulation, increasing pesticide penetration, increasing sun exposure. Pruning of leaves which directly touch clusters is advisable. Excessive nitrogen application should be avoided. Susceptible cultivars should be avoided. Grape berry moth and other insect pest which damage clusters should be managed to lessen the infection opportunities.

\section{Chemical}

A mixture of Difenoconazole with Cyprodinil and Tebuconazole with Fluopyram is reported to be effective in some grape cultivar. For proper, penetration of fungicide, the long vines should be trimmed before applying chemicals.

\section{Biological}

Bacillus subtilis is found to be effective against this disease in some cultivars.

\section{Crown gall}

It is a bacterial disease and caused by Agrobacterium tumefaciens. The bacteria enter through wounds. The disease affects almost all grape cultivars. Due to the galls produced on trunks, severe yield loss occurs which lead to major economic losses.

\section{Symptoms}

Initially, a small, spherical, white to fleshy colored, soft gall appears near the soil level of the trunk. The galls develop rapidly and as the galls become older, they turn in to dark brown, knotty, and rough. These galls are responsible for the translocation of water and nutrients, followed by gradual dieback, poor growth and death of the vine. In severe cases, infected vines become stunted.

\section{Management}

\section{Cultural}

To control the disease proper water management is an important step. Healthy planting materials should be used. Plant injuries should be avoided.

\section{Biological}

Non-pathogenic Agrobacterium (K84) is an important strain to control this disease. It is observed that when a non-pathogenic strain of A. vitis, is applied to wounded grape tissue in advance of gall-forming pathogen, crown gall is prevented.

\section{Chemical}

There are no current chemical control recommendations for crown gall on grapes. 


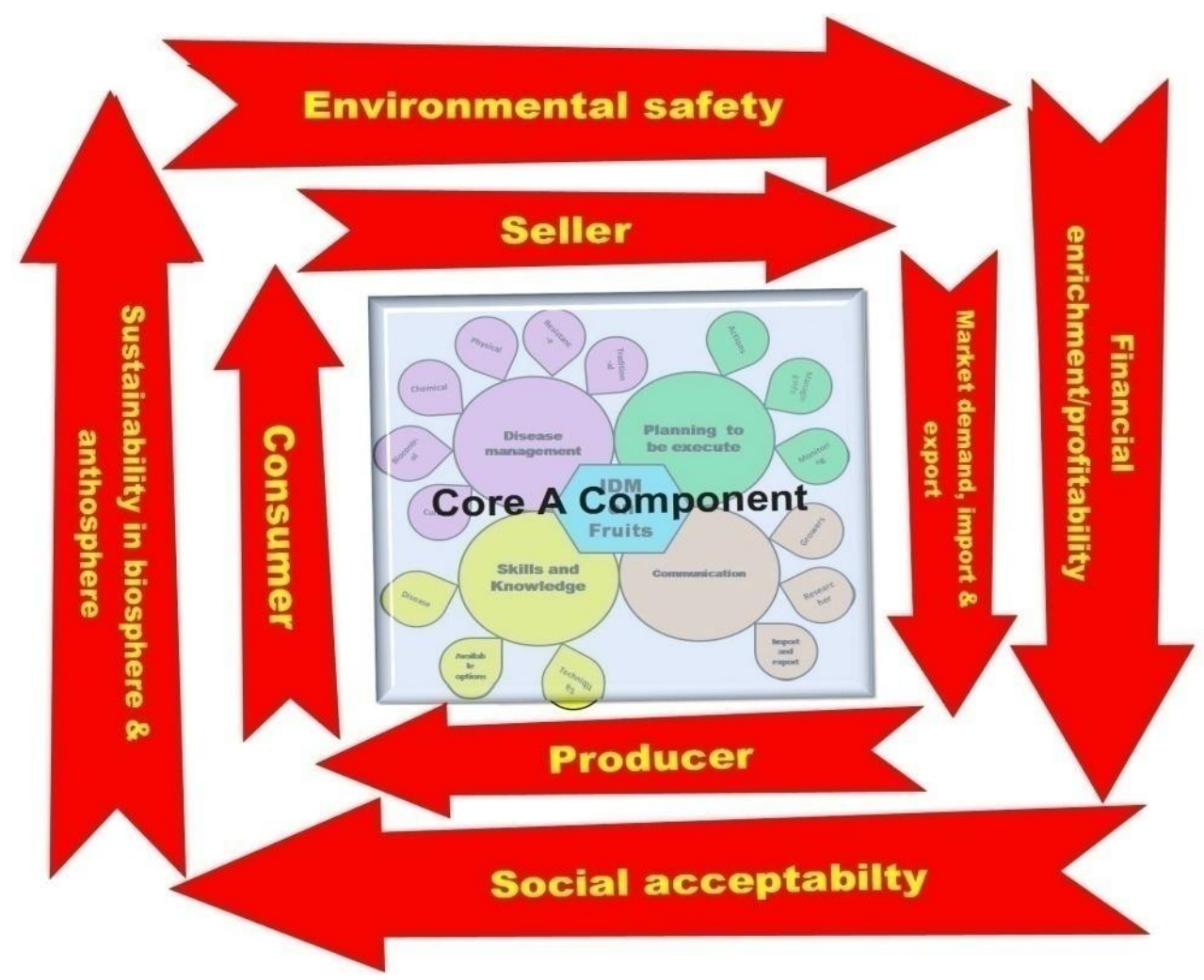

Figure.1 Farmers centric problem prioritization and their concentric solution represented through IDM model

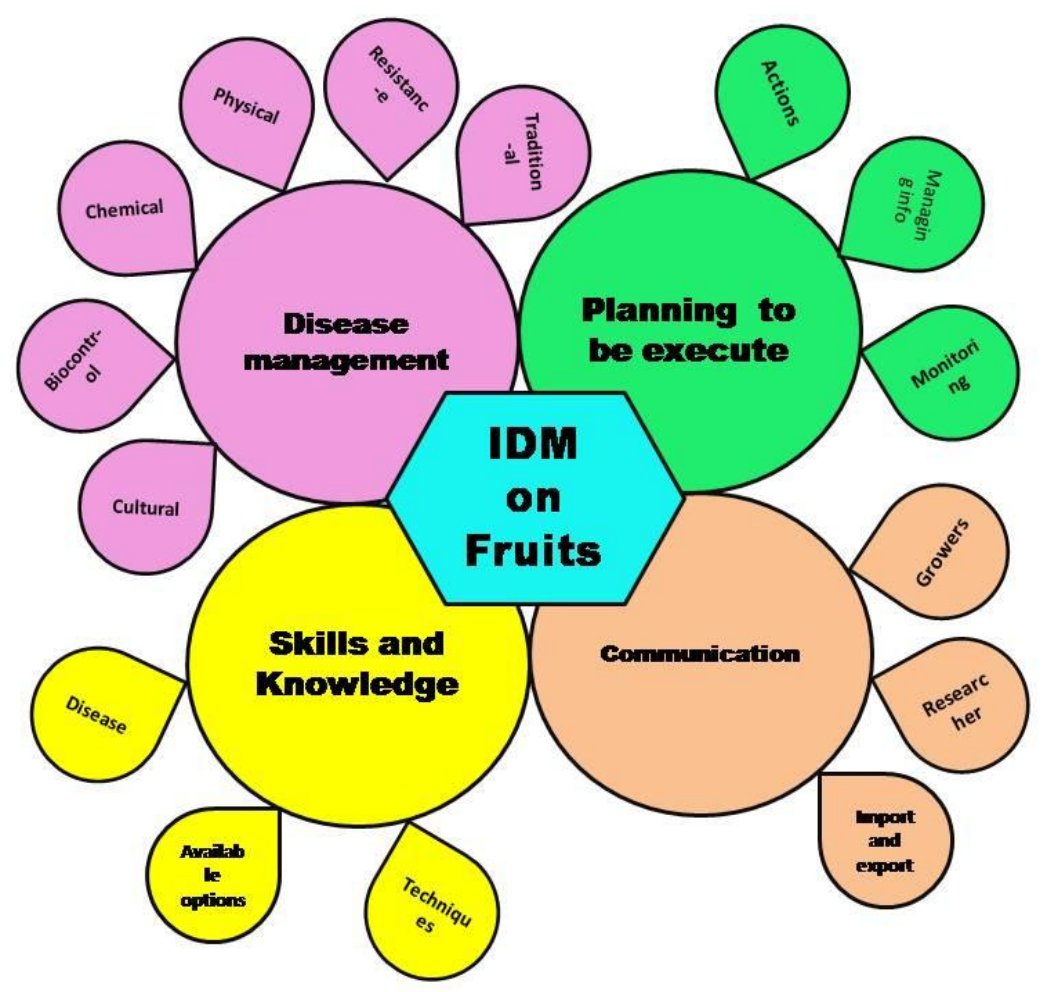

Figure.2 Schematic representation of core A component of IDM 


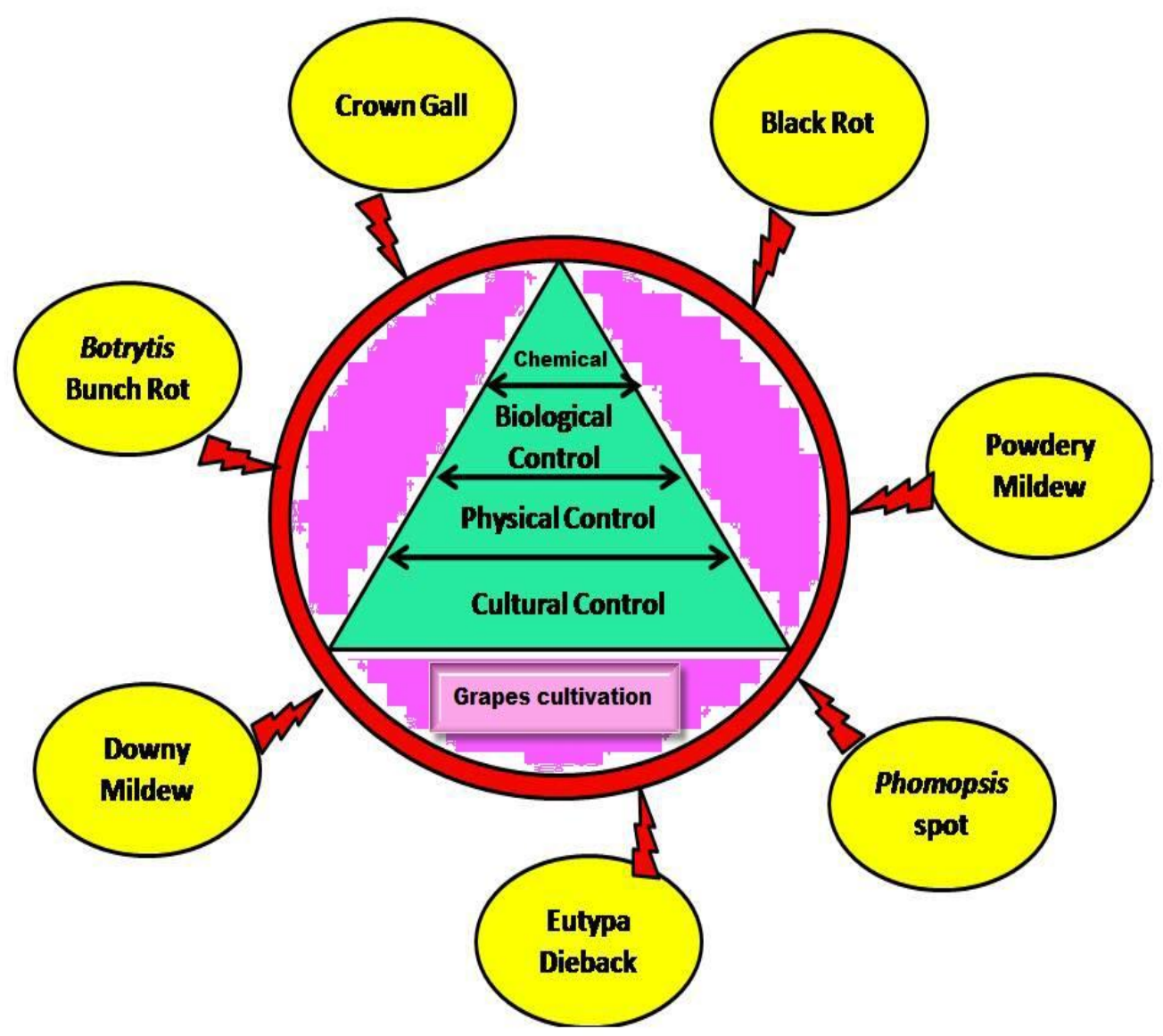

Figure.3 Schematic representation of biotic stresses on grapes production and their concentric IDM components in chronological order

Integrated disease management is the potential tool kit to manage diverse plant pathogens with a very systematic way. IDM practices found to be widely adoptable for its cost effectiveness, faster controlling activity and environment friendly approach. IDM strategies are the consortium of all probable management strategies against a specific disease. Among the all usable control measure using of disease resistant and tolerant variety are found to be effective. It's advised about chemical methods under IDM, not to use frequently or use under limit line by which pathogenic resistance will not create against a specific agro-chemical. Tough biological control measures were consider to be the most crucial eco-friendly management strategy but due to insufficient knowledge in disease profile and pathogen biology most of the farmers declining to adopt the same at initial stage. To mitigate increasing demand and inadequate research on different biocontrol agents opens the platform of hyper parasitism, induced resistance, hypo virulence or competition etc. IDM approaches on grapes turned to be more fruitful when simultaneously more than pathogen can control with common management strategy, which is a matter of progressive research. Government initiating various act, regulation and policies through national horticultural mission motivates grass hood level fruit cultivars to some extent. By organizing different awareness programmes, training, 
workshops skills will be distributed to the farmer's community. Providing agri-funding and support through different policies, loans can fulfill the basic needs of small farmers. Time to time evaluating of those policies, bringing external agencies as funding source and working with NGO's can motivate all classes of farmers and whole farming system. Indian economy stands on agricultural system, therefore it's our sole responsibility to follow and maintain IDM principles and protective measure within its limit line.

\section{Conflict of interest}

\section{Manuscript title}

"Integrated disease management on grapes A pioneer of a reformed movement towards sustainability - Review”.

\section{Authors name}

Siddhartha Das and Sudeepta Pattanayak.

The authors whose names are mentioned above, solemnly and confidently declared that they have no any conflict of interest. They have not attached with any other academic or research institutes, except the mentioned affiliation in terms of contribution. Additionally they also declared that they are not attached with any kind of financial interests or non-financial (or personal interests) interests with any other organization or person. The subject matter of this chapter is totally original and unique or if taken from any other literature properly cited under the references of this manuscript.

\section{References}

Baker K.F., Cook R.J., 1974. Biological Control of Plant Pathogens. Freeman W.H. \& Co., San Francisco, USA.

Buddenhagen I.W., 1977. Resistance and vulnerability of tropical crops in relation to their evolution and breeding. Annalsof the New York Academy of Science. 287: 309-326.

Cook R.J., Bruckart W.L., Coulson J.R., Goettel M.S., Humber R.A., 1996. Safety of microorganisms intended for pest and plant disease control: a framework for scientific evaluation. Biological Control. 7: 333-351.

De Waard M.A., Georgopoulos S., Hollomon G.D.W., Ishii H., Leroux P., Ragsdale N.N., Schwinn F.J., 1993. Chemical control of plant diseases: problems and prospects. Annual Review of Phytopathology. 31: 403-421.

Gullino M.L., Leroux P., Smith C.M., 2000. Uses and challenges of novel compounds for plant disease control. CropProtection. 19: 1-11.

Hagmann J., Chuma E., Murwira K., Connolly M., 1999. Putting process into practice, Operationalizing participatory extension. Network Paper, Agricultural Research and Extension Network, ODI (UK), No. 94.

Harman G.E., Bjorkman T., 1998. Potential and existing uses of Trichoderma and Gliocladium for plant disease control and growth enhancement. In: Harmon G.E., Kubicek C.P. (eds). Trichoderma and Gliocladium, vol. 2: Enzymes, Biological Control and Commercial Applications, pp. 229-265. Taylor and Francis, London, UK.

Hewitt HG. 1998. Fungicides in Crop Protection. CAB International, Wallingford, UK

Kerr A., 1980. Biological control of crown gall through production of agrocin 84 . Plant Disease. 64: 25-30.

Khoury W. El and Makkouk K. 2010. Integrated plant disease management in developing countries. Journal of Plant Pathology. 2010, 92 (4, Supplement), S4.35-S4.42 Edizioni ETS Pisa, 2010. 
Knight S.C., Anthony V.M., Brady A.M., Greenland A.J., Heaney S.P., Murray D.C., Powell K.A., Schultz M.A., Spinks C.A., Worthington P.A., Youle D., 1997. Rationale and perspectives on the development of fungicides. Annual Review of Phytopathology. 35: 349372.

Lumsden R.D., Walter J.F., 1995. Development of biocontrol fungus Gliocladium virens: risk assessment and approval for horticultural use. In: Hokkanen M.T., Lynch J.M. (eds). Biological Control: Benefits and Risks, pp. 263-269. Cambridge University Press, Cambridge, UK.

Overton J., 1996. Ecologically Based Pest Management-New Solutions for a New Century. National Academy Press, Washington DC, USA.

Röling N., Pretty J.N., 1997. Extension's role in sustainable agricultural development. In: Burton Swanson E., Bentz R.P., Sofranko A.J. (eds). Improving Agricultural Extension. A Reference Manual. FAO pulbvication Division, Rome, Italy.

Schillhorn van Veen T., 1999. Agricultural pest management at a crossroads: New opportunities and new risks. Food and Fertilizer Technology Centre for Asia and the Pacific Region, Extension Bulletin. 01-04-1999.

Sorby K., Fleischer G., Pehu E., 2003. Integrated Pest Management in Development: Review of Trends and Implementation Strategies. Agriculture and Rural Development. Working Paper 5. World Bank. Washington DC, USA.

SP-IPM, 2008. Incorporating Integrated Pest Management into National Policies. IPM Research Brief No. 6. SP-IPM Secretariat, International Institute of Tropical Agriculture (IITA), Ibadan, Nigeria.

Sulaiman R. and Hall A. 2002. Beyond technology dissemination: reinventing agricultural extension. Outlook on Agriculture. 31:225-233.

Van de Fliert E., Asmunati R.,. Tantowijoyo W. 2000. Participatory approaches and scaling-up. In: Stür W.W., Horne P.M, Hacker J.B., Kerridge P.C. (eds). Working with farmers: the key to adoption of forage technologies. ACIARP roceedings. No. 95, International Workshop, Cayagan de Oro City, Mindanao 1999: 83-90.

\section{How to cite this article:}

Siddhartha Das and Sudeepta Pattanayak. 2020. Integrated Disease Management on Grapes - A Pioneer of a Reformed Movement towards Sustainability. Int.J.Curr.Microbiol.App.Sci. 9(05): 993-1005. doi: https://doi.org/10.20546/ijcmas.2020.905.109 